\title{
GAYA KEPEMIMPINAN PENGARUHNYA TERHADAP KINERJA KARYAWAN LARISSO SWALAYAN AMBULU
}

\author{
HENDRI SUPARTO* \\ AYU RATNASARI \\ Program Studi Ilmu Administrasi Niaga \\ Sekolah Tinggi Ilmu Administrasi Pembangunan Jember \\ *Email: hendri_suparto@stiapembangunanjember.ac.id
}

\begin{abstract}
ABSTRAK
Tujuan penelitian ini untuk menganalisis pengaruh gaya kepemimpinan otokratis dan demokratis terhadap kinerja karyawan Larisso Swalayan Ambulu. Penelitian ini merupakan penelitian kuantitatif dengan pendekatan explanatory (sebab akibat). Populasi dalam penelitian ini adalah 80 karyawan Swalayan Larisso Ambulu. Pengambilan sampel dalam penelitian ini menggunakan teknik sampling jenuh atau teknik sensus dimana semua anggota populasi dijadikan sampel. Metode analisis adalah analisis regresi linier berganda dengan menggunakan software SPSS.

Data-data yang telah dikumpulkan memenuhi uji validitas, uji reliabilitas, dan uji asumsi klasik. Hasil penelitian menunjukkan bahwa tiga hipotesis yang diajukan dalam penelitian ini diterima seluruhnya. Kepemimpinan otokratis dan demokratis berpengaruh signifikan terhadap kinerja karyawan di Larisso Swalayan Ambulu secara simultan dengan nilai

$F_{\text {hitung }}=17,632>F_{\text {tabel }}=2,72$ dan nilai signifikansi $<0,05$. Kepemimpinan otokratis berpengaruh signifikan terhadap kinerja karyawan di Larisso

Swalayan Ambulu secara parsial dengan nilai $t_{\text {hitung }}=4,706>t_{\text {tabel }}=1,664$ dan nilai signifikansi $<0,05$. Kepemimpinan demokratis berpengaruh signifikan terhadap kinerja karyawan di Larisso Swalayan Ambulu secara parsial dengan nilai $t_{\text {hitung }}=3,003>t_{\text {tabel }}=1,664$ dan nilai signifikansi $<0,05$.
\end{abstract}

Kata Kunci: Kepemimpinan Otokratis, Kepemimpinan Demokratis, Kinerja

Karyawan 


\section{PENDAHULUAN}

Gaya kepemimpinan ini seringkali menjadi dorongan atau bahkan mungkin hambatan bagi karyawannya dalam menjalankan tugas dan kegiatan sehari-hari. Menurut Bernardin dan Russel dalam (Ruky, 2005:15) Kinerja karyawan adalah cacatan tentang hasil-hasil yang diperoleh dari fungsi-fungsi pekerjaan tertentu atau kegiatan dalam kurun waktu tertentu. Pemimpin disini dituntut untuk memuaskan berbagai jenis kebutuhan yang pada gilirannya akan mepengaruhi perilaku dan kinerja karyawan.

Seorang pemimpin merupakan contoh, panutan, idola dan pembina bagi seluruh anggota organisasi yang dipimpinnya dalam meningkatkan hasil kerja. Wujud dari kepemimpinan antara lain perilaku, sikap, watak serta kebijakan yang dimiliki oleh pimpinan yang diaplikasikan dalam bidang pekerjaan atau organisasi. Karena adanya suatu keterbatasan atau kelebihan-kelebihan tertentu pada manusia maka perlu adanya koordinasi, oleh sebab itu diperlukan seorang pemimpin. Peran pemimpin dalam kehidupan organisasi sangat dibutuhkan karena tidak ada organisasi tanpa seorang pemimpin. Idealnya seorang pemimpin harus dapat memberikan semangat dan motivasi kepada karyawannya dalam menyelesaikan pekerjaan dan agar para karyawan dapat meningkatkan kualitas kehidupan kerja mereka. Dengan demikian para karyawannya akan berusaha secara terus menerus untuk meningkatkan kinerjanya, sehingga dapat meningkatkan produktivitas yang pada akhirnya bisa memberikan keuntungan bagi perusahaan.

Demikian halnya dengan Larisso Swalayan Ambulu adalah perusahaan yang bergerak di bidang jasa perdagangan, yaitu penyedia barang kebutuhan sehari-hari, mulai dari eceran sampai grosir. Larisso Swalayan adalah toko terbesar di Ambulu yang mempunyai karyawan sebanyak 80 orang dan berdiri sejak tahun 2007. Perkembanganya cukup pesat dan penulis menilai tidak terlepas dari gaya atau tipe manajer yang memimpinnya, karena 
merekalah yang memberikan arahan pekerjaan setiap saat. Peneliti memilih Larisso Swalayan Ambulu untuk dijadikan objek penelitian karena Larisso merupakan swalayan pertama yang ada di Ambulu dan masih menjadi tempat favorit berbelanja masyarakat Ambulu dan sekitarnya.

Dari hasil wawancara peneliti dengan HRD Larisso Swalayan, kualitas kinerja ideal karyawan yang diharapkan adalah tenaga-tenaga produktif yang mempunyai pengetahuan-pengetahuan yang cukup, mempunyai inisiatif, disiplin, bisa bekerja sama dengan temanteman sejawat dengan baik, loyal, dan yang paling utama adalah mempunyai kepribadian yang baik (santun dan jujur). Tetapi untuk memperoleh karyawan dengan kualitas ideal sangatlah sulit maka dengan jalan pintas manajer merekrut karyawan dengan kualitas yang mendekati ideal (dipandang baik) kemudian mendidik dan melatih mereka agar berperilaku produktif.

Akan tetapi HRD juga mengatakan bahwa kinerja karyawan pada Larisso Swalayan Ambulu sempat mengalami penurunan dalam bekerja ditandai dengan kualitas kerja, kuantitas, dan waktu penyelesaian yang tidak sesuai ketentuan. Penurunan kualitas kerja diindikasi dari adanya sifat malas karyawan yang membuat pekerjaan yang dilakukan tidak membuahkan hasil yang baik dan maksimal. Penurunan kualitas kerja diindikasikan dari karyawan yang jenuh berada di dalam ruangan swalayan dan karyawan merasa jam istirahat yang diberikan masih kurang. Sementara itu, penurunan waktu penyelesaian kerja diindikasikan dari adanya kasir yang tutup pada saat jam selesai istirahat, sehingga mengakibatkan antrian yang panjang. Ada beberapa karyawan juga yang sempat mengeluh tentang pemimpin mereka, beberapa dari mereka mengatakan bahwa pemimpin sering meminta saran, akan tetapi saran itu sering ditolak, karena itulah banyak karyawan yang malas memberikan inisiatif dan ide karena takut saran mereka ditolak. 
Kinerja dalam organisasi merupakan jawaban dari berhasil atau tidaknya tujuan organisasi yang telah ditetapkan, para atasan atau manajer sering tidak memperhatikan hal tersebut kecuali sudah amat buruk atau segala sesuatu jadi serba salah, seringkali manajer tidak mengetahui betapa buruknya kinerja karyawan sehingga perusahaan menghadapi krisis yang serius. Hal tersebut menyebabkan terjadinya kesan-kesan buruk organisasi mendalam akibat mengabaikan

\section{TINJAUAN PUSTAKA}

\subsection{Kepemimpinan}

Dalam sebuah organisasi dipastikan akan memerlukan seorang pemimpin, keberhasilan atau kegagalan sebuah organisasi terletak pada pemimpin dalam mengelola organisasi. Menurut Sutrisno (2010:213), kepemimpinan adalah suatu proses kegiatan seseorang untuk menggerakkan orang lain dengan memimpin, membimbing, memengaruhi orang lain, untuk melakukan sesuatu agar hasil yang diinginkan tercapai. Sedangkan menurut Indrawijaya (2000:141), tanda-tanda peringatan adanya kinerja yang menurun. Disinilah peran manajer menggunakan kemampuan gaya kepemimpinannya untuk memengaruhi karyawan baik yang masih baru maupun yang sudah lama.

Berdasarkan uraian permasalahan, maka peneliti tertarik untuk meneliti pengaruh gaya kepemimpinan otokratis dan demokratis terhadap kinerja karyawan Larisso Swalayan Ambulu.

kepemimpinan adalah kemampuan memengaruhi dan menggerakan orang lain, sehingga mereka bertindak dan berperilaku sebagaimana yang diharapkan, terutama bagi tercapainya tujuan yang diinginkan. Kepemimpinan dapat pula dipandang sebagai bentuk persuasi suatu seni pembinaan sekelompok orang tertentu, biasanya melalui pendekatan dan motivasi yang tepat sehingga mereka tanpa ada rasa takut untuk bekerja sama dalam mencapai tujuan organisasi. Peran pemimpin dalam memberikan 
konstribusi pada karyawan untuk pencapaian kinerja yang optimal dilakukan melalui lima cara, yaitu:

1. Pemimpin mengklarifikasi apa yang diharapkan dari karyawannya, secara khusus tujuan dan sasaran dari kinerja mereka.

2. Pemimpin menjelaskan bagaimana cara memenuhi harapan tersebut.

3. Pemimpin mengemukakan kriteria dalam melakukan evaluasi dari kinerja secara efektif.

4. Pemimpin memberikan umpan balik ketika karyawan telah mencapai sasaran.

5. Pemimpin mengalokasikan imbalan berdasarkan hasil yang telah mereka capai.

\subsection{Gaya Kepemimpinan}

Gaya kepemimpinan seorang pemimpin sangat memengaruhi keberhasilan organisasi dalam mencapai tujuannya. Perilaku seorang pemimpin memiliki dampak yang besar pada sikap dan perilaku bawahan yang akhirnya berdampak pada kinerja. Menurut Heidjrachman, et.al (2002:219), dalam hubungannya dengan kinerja dijelaskan corak atau gaya kepemimpinan seseorang sangat berpengaruh terhadap pencapaian tujuan suatu organisasi. Dalam praktiknya, menurut Siagian (2001:57), berkembang beberapa gaya kepemimpinan, diantaranya adalah sebagai berikut:

1. Gaya Otokratis

Seorang pemimpin yang otokratis ialah pemimpin yang memiliki beberapa kriteria sebagai berikut:

a. Menganggap organisasi sebagai pemilik pribadi.

b. Mengidentikan tujuan pribadi dengan tujuan organisasi.

c. Tidak mau menerima kritik, saran dan pendapat.

d. Terlalu tergantung pada kekuasaan formalnya.

e. Dalam tindakan
pergerakannya menggunakan pendekatan yang mengandung unsur paksaan dan bersifat menghukum.

f. Menganggap bawahannya sebagai alat semata. 
2. Gaya Demokratis

Pengetahuan

tentang

kepemimpinan

telah

membuktikan bahwa tipe

pemimpin yang demokratislah yang paling tepat untuk organisasi modern. Ciri-ciri dari gaya kepemimpinan demokratis adalah sebagai berikut:

a. Senang menerima saran, pendapat dan bahkan kritikan dari bawahan.

b. Selalu berusaha mengutamakan kerjasama dalam usaha mencapai tujuan.

c. Selalu berusaha menjadi lebih sukses dari sebelumnya.

d. Selalu mengembangkan kapasitas diri pribadinya sebagai pemimpin.

Dari gaya kepemimpinan diatas penulis mengambil dua gaya kepimimpinan yang umum dan cocok diterapkan di dunia bisnis yaitu gaya kepemiminan otokratis dan gaya kepemimpinan dekmokratis.

\subsection{Kinerja Karyawan}

Selanjutnya Dharma (2001:149) mengungkapkan untuk dapat menilai kinerja karyawan secara objektif dan akurat adalah dengan mengukur tingkat kinerja karyawan. Pengukuran kinerja dapat juga berfungsi sebagai upaya mengumpulkan informasi yang dapat digunakan untuk mengarahkan upaya karyawan melalui serangkaian prioritas tertentu, seperti komunikasi. Ukuran kinerja mencakup beberapa tipe kriteria performansi kinerja yang didasarkan atas deskripsi perilaku yang spesifik, antara lain (Gomez, 2000:142):

1. Quantity of work, yaitu jumlah hasil kerja yang didapat dalam suatu periode waktu yang ditentukan.

2. Quality of work, yaitu kualitas kerja yang dicapai berdasarkan syarat-syarat kesesuaian dan kesiapannya.

3. Job knowledge, yaitu luasnya pengetahuan mengenai pekerjaan dan ketrampilannya.

4. Creativeness, yaitu keaaslian gagasan-gagasan yang dimunculkan dan tindakan- 
tindakan untuk menyelesaikan persoalan-persoalan yang timbul.

5. Cooperative, yaitu kesediaan untuk bekerja sama dengan orang lain (sesama anggota organisasi).

6. Dependability, yaitu kesadaran dalam melakukam pekerjaan dan dapat dipercaya (jujur) dalam hal kehadiran baik (disiplin) dan penyelesaian kerjanya baik.

7. Initiative, yaitu semangat untuk melaksanakan tugas-tugas baru dan dalam memperbesar tanggung jawabnya.

8. Personal qualities, yaitu menyangkut kepribadian, kepemimpinan,

keramahtamahan dan integrasi pribadi.

\subsection{Manajemen Kerja}

Dalam mendesain manajemen kinerja ada dua prinsip dasar yang harus ada:

1. Manajemen kinerja harus memberikan kejelasan visi, misi dan tujuan institusi dalam rangka mewujudkan keinginan atau sasaran institusi atau sasaran unit kerja.

2. Manajemen kinerja harus memberikan kejelasan standar yang berkaitan dengan uraian tugas, sasaran indikator keberhasilan utama bagi pemegang jabatan. Uraian tugas adalah pokok-pokok tugas dan cakupan tanggung jawab utama dari suatu jabatan tertentu. Biasanya uraian tugas atau uraian jabatan dari masingmasing karyawan. Sasaran (target) merupakan jabatan dari uraian tugas dalam bentuk sasaran pecapaian keberhasilan kegiatan dalam periode tertentu atau periode penilaian. Indikator keberhasilan adalah indikatorindikator yang dapat mengukur tercapai tidaknya sasaran.

\subsection{Penilaian Kerja}

Menurut Setiyaningrum, A (2004), ada tiga alasan yang mendasar mengapa organisasi perlu melakukan penilaian kinerja:

1. Individu direkrut oleh organisasi untuk menunjukkan kinerja yang diperlukan guna mengsukseskan 
organisasi. Penilaian kinerja digunakan sebagai cara organisasi dalam menentukan apakah individu tersebut layak atau tidak direkrut.

2. Individu memiliki kemampuan bekerja dan kesetiaan terhadap komitmen kerja yang berbeda antar individu satu dengan individu lain. Penilaian kinerja diperlukan untuk mencatat perbedaan kontribusi yang diberikan oleh masing-masing individu kepada organisasi.

3. Dalam situasi hukum saat ini, penilaian kinerja formal sangat diperlukan untuk melindungi tindakan negatif organisasi terhadap individu, khususnya tidakan yang memengaruhi anggota kelompok minoritas yang dilindungi oleh hukum.

\section{METODE PENELITIAN}

Penelitian ini dilakukan di Larisso Swalayan Ambulu yang terletak di Jl. Watu Ulo Kec. Ambulu Kab. Jember. Operasional penelitian dilakukan selama tiga bulan, yaitu pada bulan Juni-Agustus tahun 2017.

\subsection{Hipotesis}

Hipotesis dalam penelitian ini adalah sebagai berikut:

$$
\begin{array}{rlr}
\mathrm{H}_{1} & \text { : Gaya kepemimpinan } \\
& \text { otokratis dan demokratis } \\
& \text { berpengaruh } & \text { signifikan } \\
& \text { terhadap kinerja karyawan } \\
& \text { Larisso Swalayan Ambulu } \\
& \text { secara simultan. } \\
\mathrm{H}_{2} & \text { : Gaya kepemimpinan } \\
& \text { otokratis berpengaruh } \\
& \text { signifikan terhadap kinerja } \\
& \text { karyawan } \\
& \text { Swalayan Ambulu secara } \\
& \text { parsial. } \\
\mathrm{H}_{3} & \text { Gaya } \\
& \text { demokratis } \quad \text { berpengaruh } \\
& \text { signifikan terhadap kinerja } \\
& \text { karyawan } \\
& \text { Swalayan Ambulu secara } \\
& \text { parsial. }
\end{array}
$$

Populasi yang digunakan dalam penelitian ini adalah karyawan bagian area market, fashion, dan perlengkapan pada Larisso Swalayan Ambulu yang berjumlah 80 orang. Dalam penelitian ini proses pengambilan data menggunakan 
metode sensus dimana jumlah populasi sama dengan jumlah sampel.

Jenis data yang digunakan dalam penelitian ini adalah data kuantitatif. Data diperoleh dengan instrumen kuesioner dengan jenis data interval yang mempunyai hubungan kausal.

Sumber data yang digunakan dalam penelitian ini adalah data primer dan data sekunder:

1. Data Primer, adalah data yang diperoleh secara langsung dari sumbernya yaitu responden, dengan cara:
a. Kuesioner, dilakukan dengan cara menyebarkan daftar pertanyaan pada karyawan Larisso Swalayan Ambulu.

b. Wawancara, melakukan wawancara langsung kepada manajer selaku pimpinan dan karyawan.

c. Survey, melakukan survey lokasi penelitian di Larisso Swalayan Ambulu.

2. Data Sekunder, adalah data yang diperoleh dengan mencari data dari kantor Larisso Swalayan dan mempelajari bahan-bahan dari buku, website, dan hasil penelitian yang dapat dipakai sebagai acuan dalam pembuatan penelitian.

Skala pengukuran pada penelitian ini menggunakan empat tanggapan jawaban dengan skala likert yang diberi skor: 4, 3, 2, 1 dimana 4 bermakna Setuju (S), 3 bermakna Cukup Setuju (CS), 2 bermakna Kurang Setuju (KS), dan 1 bermakna Tidak Setuju (TS).

\section{HASIL PENELITIAN DAN PEMBAHASAN}

Kuesioner yang disebarkan dalam penelitian ini berjumlah 80 kuesioner dengan responden karyawan di Larisso Swalayam. Kuesioner yang kembali juga berjumlah 80 , jadi response rate dalam penelitian ini adalah 100\%, artinya semua jawaban lengkap dan layak digunakan untuk analisa. 
Profil responden berdasarkan jenis kelamin menunjukkan bahwa karyawan perempuan lebih banyak dengan frekuensi 45 orang atau dengan presentase sebesar 56,0\% sedangkan laki-laki dengan frekuensi 35 orang atau dengan presentase $44,0 \%$. Hasil ini sesuai dengan harapan perusahaan karena jasa pelayanan perlu penampilan yang menarik, dalam hal ini pegawai perempuan dipandang lebih menarik, ramah dan memyenangkan.

Profil responden berdasarkan usia menunjukkan bahwa usia responden 17-25 tahun sebanyak 50 orang atau dengan persentase $62,0 \%$ usia muda yang dominan, pada usia 26-34 tahun sebanyak 25 orang atau dengan persentase $31,0 \%$, dan pada usia $\geq 35$ tahun sebanyak 5 orang atau dengan persentase 7,0\%. Hal ini sesuai dengan keinginan perusahaan untuk memberdayakan tenaga kerja yang masih muda dan sesuai faktor kebutuhan tenaga kerja.

\subsection{Uji Validitas dan Reliabilitas}

Jumlah sampel dalam penelitian ini adalah 80 dan besarnya df dapat dihitung 80-2=78. Dengan $\mathrm{df}=78$ dan pada taraf signifikan $95 \%$ atau alpha $(\alpha) 5 \%$ diperoleh $r_{\text {tabel }}=$ 0,2199. Jika $r_{\text {hitung }}>r_{\text {tabel }}$ dan nilai positif maka item pertanyaan atau indikator dinyatakan valid.

Berdasarkan uji validitas menunjukkan bahwa item pernyataan yang digunakan peneliti untuk mengukur variabel yang digunakan dalam penelitian ini mempunyai nilai $r_{\text {hitung }}$ yang lebih besar dari pada $r_{\text {tabel }}$ sehingga semua item pernyataan (indikator) dinyatakan lolos dalam uji validitas atau dinyatakan sebagai data yang valid.

Berdasarkan uji reliabilitas dapat diketahui nilai Cronbach Alpha seluruh item variabel > 0,6. Maka dapat dapat disimpulkan bahwa seluruh item pernyataan yang digunakan dalam penelitian ini dinyatakan reliabel.

\subsection{Uji Asumsi Klasik}

Uji normalitas pada penelitian ini menggunakan pengukuran Kolmogorov-Smirnov yang hasilnya dapat dilihat pada Tabel 1 . Berdasarkan Tabel 1 menunjukkan bahwa nilai Kolmogorov-Smirnov $Z$ dan Asyimp. Sig dalam penelitian ini 
adalah 0,752 dan 0,624 maka dapat disimpulkan bahwa data dalam penelitian adalah berdistribusi normal karena nilai KolmogorovSmirnov $Z$ dan Asymp. Sig lebih besar dari 0,05 .

Tabel 1. Hasil Uji Normalitas

One-Sample Kolmogorov-Smirnov Test

\begin{tabular}{|ll|r|}
\hline & & $\begin{array}{r}\text { Unstandardized } \\
\text { Residual }\end{array}$ \\
\hline $\mathrm{N}$ & Mean & 80 \\
Normal Parameters & a,b &, 0000000 \\
Most Extreme Differences & Std. Deviation & 1,34378158 \\
& Absolute &, 084 \\
& Positive &, 057 \\
Kolmogorov-Smirnov Z & Negative &,- 084 \\
Asymp. Sig. (2-tailed) & &, 752 \\
\end{tabular}

a. Test distribution is Normal.

b. Calculated from data.

Uji heteroskedastisitas menggunakan grafik plot (scatterplot) dimana persebaran titiktitiknya dapat dilihat pada Gambar 1. Berdasarkan hasil grafik scatterplot memperlihatkan bahwa titik-titik menyebar secara acak serta tersebar di atas maupun di bawah angka 0 pada sumbu $y, \quad$ serta tidak mempunyai pola yang jelas atau tidak membentuk suatu pola. Untuk itu dapat disimpulkan bahwa tidak terjadi heteroskedastisitas pada model regresi, sehingga model regresi layak dipakai sebagai alat prediksi. 


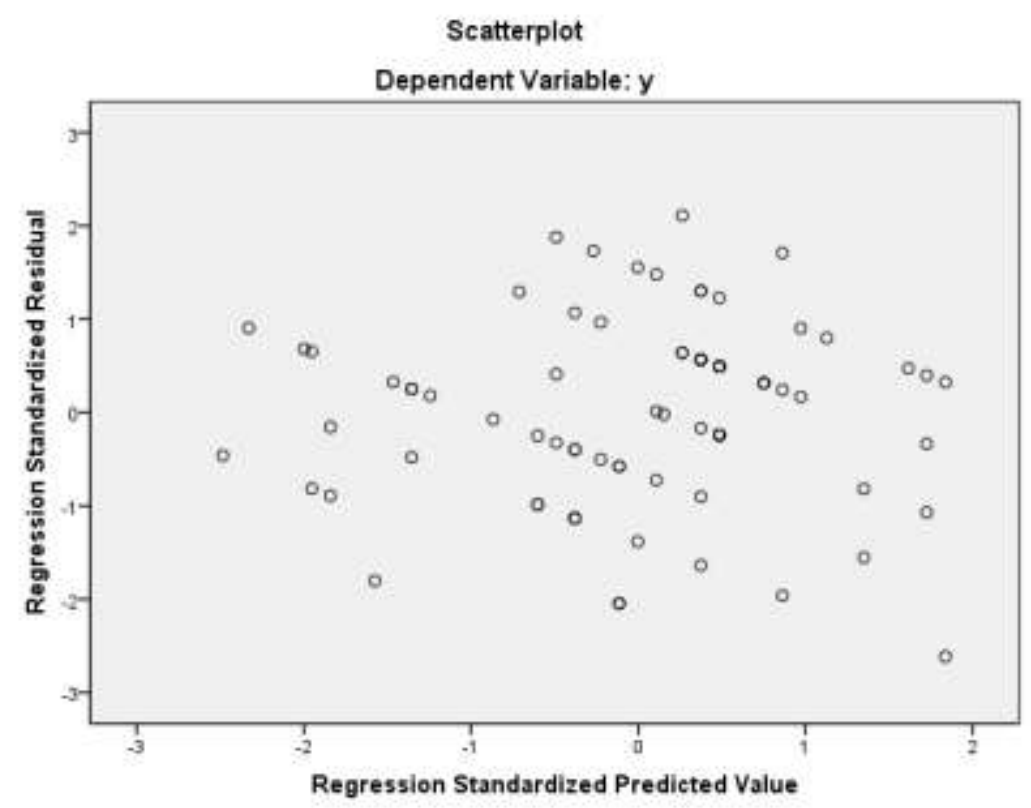

Gambar 1. Hasil Uji Heteroskedastisitas

Untuk mendeteksi ada atau dari 10 maka terjadi tidaknya multikolinieritas di dalam multikolinieritas, sebaliknya tidak model regresi pada penelitian ini terjadi multikolinieritas antar menggunakan VIF (Variance variable independen apabila nilai Inflation Factor). Apabila nilai VIF VIF berada pada 0,10 sampai 10. lebih kecil dari 0,10 atau lebih besar

Tabel 2. Hasil Uji Multikolinieritas

\begin{tabular}{|l|r|c|}
\hline \multirow{2}{*}{ Model } & \multicolumn{2}{|c|}{ Collinearity Statistics } \\
\cline { 2 - 3 } & Tolerance & \multicolumn{1}{|c|}{ VIF } \\
\hline (Constant) &, 984 & \\
x1 &, 984 & 1,016 \\
x2 & & 1,016 \\
\hline
\end{tabular}

a. Dependent Variable: y

Berdasarkan Tabel 2 di atas menunjukkan bahwa dalam model regresi tidak terjadi multikolinieritas atas korelasi yang sempurna antara variabel-variabel bebas, yaitu gaya kepemimpinan otokratis dan demokratis, karena nilai VIF lebih kecil dari 10 dan nilai tolerance lebih besar dari 0,10 . 


\subsection{Analisis Regresi Linier Berganda}

Tabel 3. Hasil Analisis Regresi Linier Berganda

\begin{tabular}{|c|c|c|c|c|c|c|}
\hline \multirow{2}{*}{\multicolumn{2}{|c|}{ Model }} & \multicolumn{2}{|c|}{ Unstandardized Coefficients } & \multirow{2}{*}{$\begin{array}{c}\text { Standardized } \\
\text { Coefficients } \\
\text { Beta }\end{array}$} & \multirow[b]{2}{*}{$\mathrm{T}$} & \multirow[b]{2}{*}{ Sig. } \\
\hline & & $\mathrm{B}$ & Std. Error & & & \\
\hline \multirow[t]{3}{*}{1} & (Constant) & 11,863 & 2,293 & & 5,174 &, 000 \\
\hline & $x 1$ & ,443 & ,094 & ,448 & 4,706 &, 000 \\
\hline & $x 2$ & ,343 &, 114 & ,286 & 3,003 & ,004 \\
\hline
\end{tabular}

a. Dependent Variable: y

Berdasarkan hasil analisis data pada Tabel 3 maka persamaan regresi linier berganda yang diperoleh adalah sebagai berikut:

$\mathrm{Y}=\alpha+\beta 1 \mathrm{X}_{1}+\beta 2 \mathrm{X}_{2}+\mathrm{e}$

$\mathrm{Y}=11,863+0,443 \mathrm{X}_{1}+0,343 \mathrm{X}_{2}+\mathrm{e}$

Kinerja karyawan $=11,863+0,443$

Otokratis + 0,343 Demokratis

Berdasarkan persamaan dapat diketahui bahwa:

1. Nilai konstanta sebesar 11,863 dapat diartikan apabila tidak ada pengaruh variabel kepemimpinan otokratis dan kepemimpinan demokratis (dianggap nol), maka kinerja karyawan sudah dipastikan meningkat sebesar 11,863.

2. Nilai koefisien beta pada variabel otokratis sebesar 0,443 artinya setiap perubahan variabel otokratis (X1) sebesar satu satuan maka akan mengakibatkan perubahan kinerja karyawan sebesar 0,443 satuan, dengan asumsi yang lain adalah tetap. Sebaliknya penurunan satu satuan pada variabel otokratis akan menurunkan kinerja karyawan sebesar 0,443 satuan.

3. Nilai koefisien beta pada variabel demokratis sebesar 0,343 artinya setiap perubahan variable demokratis (X2) sebesar satu satuan maka akan mengakibatkan perubahan kinerja karyawan sebesar 0,343 satuan, dengan asumsi yang lain adalah tetap. Sebaliknya penurunan satu satuan pada variabel demokratis akan menurunkan kinerja karyawan sebesar 0,343 satuan. 


\subsection{Uji Hipotesis}

\section{Uji Simultan (Uji F)}

Berdasarkan Tabel 4 diperoleh $F_{\text {hitung }}=17,632>F_{\text {tabel }}=2,72$ dengan nilai signifikansi 0,00. Karena nilai $\mathrm{F}_{\text {hitung }}>\mathrm{F}_{\text {tabel }}$ dan nilai signifikansi < 0,05 maka sesuai dengan syarat di atas berarti $\mathrm{H}_{0}$ ditolak dan menerima
$\mathrm{H}_{1}$. Sehingga dbahwa simultan variabel kepemimpinan otokratis dan kepemimpinan demokratis berpengaruh signifikan terhadap kinerja karyawan di Larisso Swalayan Ambulu.

Tabel 4. Hasil Uji F

\begin{tabular}{|ll|r|r|r|r|r|}
\hline \multicolumn{1}{|c|}{ ANOVA $^{\text {b }}$} \\
\hline 1 & Sum of Squares & Df & Mean Square & F & Sig. \\
\hline & Regression & 65,333 & 2 & 32,667 & 17,632 &, $000^{\mathrm{a}}$ \\
& Residual & 142,654 & 77 & 1,853 & & \\
& Total & 207,988 & 79 & & & \\
\hline
\end{tabular}

a. Predictors: (Constant), x2, x1

b. Dependent Variable: y

\section{Uji Parsial (Uji t)}

Berdasarkan Tabel 3 hasil dari uji t sebagai berikut:

a. Hasil pengujian diperoleh nilai $\mathrm{t}$ untuk variabel otokratis (X1) menunjukkan nilai $\mathrm{t}_{\text {hitung }}=4,706>\mathrm{t}_{\text {tabel }}=$ 1,664 dengan nilai signifikansi sebesar $0,00<$ 0,05. Dengan nilai $t_{\text {hitung }}>$ $t_{\text {tabel }}$ dan nilai signifikansi di bawah 0,05 dan koefisien regresi mempunyai nilai positif sebesar 0,443 hal tersebut menunjukkan bahwa gaya kepemimpinan otokratis memiliki pengaruh positif dan signifikan terhadap kinerja karyawan. Hal ini berarti $\mathrm{H}_{2}$ yang menyatakan bahwa "gaya kepemimpinan otokratis berpengaruh signifikan terhadap kinerja karyawan di Larisso Swalayan Ambulu" diterima.

b. Hasil pengujian diperoleh nilai $t$ untuk variabel demokratis menunjukkan nilai $t_{\text {hitung }}=$ 
$3,003>\mathrm{t}_{\text {tabel }}=1,664$ dengan

nilai signifikansi sebesar

$0,004<0,05$. Dengan nilai

$t_{\text {hitung }}>t_{\text {tabel }}$ dan nilai

signifikansi di bawah 0,05

dan koefisien regresi

mempunyai nilai positif

sebesar 0,343 hal tersebut

menunjukkan bahwa gaya

kepemimpinan demokratis

\section{KESIMPULAN DAN SARAN}

\subsection{Kesimpulan}

Dari pembahasan yang telah diuraikan maka dapat ditarik kesimpulan sebagai berikut:

1. Secara simultan variabel gaya kepemimpinan otokratis (X1) dan gaya kepemimpinan demokratis (X2) berpengaruh signifikan terhadap kinerja karyawan (Y) Larisso Swalayan Ambulu.

2. Hasil analisis secara parsial dengan menggunakan uji $t$ menunjukan bahwa gaya kepemimpian otokratis (X1) berpengaruh signifikan terhadap kinerja karyawan (Y) Larisso Swalayan Ambulu. Gaya kepemimpian demokratis memiliki pengaruh positif dan signifikan terhadap kinerja karyawan. Hal ini berarti $\mathrm{H}_{3}$ yang menyatakan bahwa "gaya kepemimpinan demokratis berpengaruh signifikan terhadap kinerja karyawan di Larisso Swalayan Ambulu" diterima.

(X2) juga berpengaruh signifikan terhadap kinerja karyawan (Y) Larisso Swalayan Ambulu.

3. Faktor paling dominan yang memengaruhi kinerja karyawan secara siginifikan di Larisso Swalayan Ambulu ini dapat dibuktikan dari hasil uji $\mathrm{t}$ dimana pengaruh gaya kepemimpinan otokratis mempunyai angka paling dominan yaitu 4,706.

\subsection{Saran}

Setelah penulis menganalisis variabel gaya kepemimpinan dan kinerja karyawan maka pihak manajemen Larisso Swalayan 
Ambulu dapat memperhatikan halhal berikut ini untuk dijadikan bahan pertimbangan dalam menjaga kelangsungan Swalayan yaitu:

1. Berdasarkan hasil penelitian pada karyawan Larisso Swalayan Ambulu diketahui bahwa variabel gaya kepemimpinan otokratis mendapat skor terendah (134) pada indikator "pemimpin mengelola toko swalayan sebagai milik sendiri”. Oleh karena itu, manajer Larisso Swalayan Ambulu disarankan untuk menganggap toko sebagai milik sendiri karena itu dapat menambah loyalitas kerja dan bisa menjadi contoh untuk para karyawan.

2. Berdasarkan hasil penelitian pada karyawan Larisso Swalayan Ambulu diketahui bahwa variabel gaya kepemimpinan demokratis

\section{DAFTAR PUSTAKA}

Atmosudirjo, S Prayudi. 1982. Beberapa Pandangan Umum tentang Pengendalian Keputusan. Cetakan IV. Jakarta: Ghalia Indonesia. mendapat skor terendah (156) pada indikator "pimpinan anda selalu memberi kebebasan kepada bawahan untuk memberikan saran". Oleh karena itu, manajer Larisso Swalayan Ambulu disarankan untuk lebih memberi kebebasan pada karyawan untuk memberikan saran untuk membuat toko jauh lebih maju.

3. Berdasarkan hasil penelitian pada karyawan Larisso Swalayan Ambulu diketahui bahwa variabel kinerja karyawan mendapat skor terendah (249) pada indikator "anda memiliki inisiatif dalam bekerja”. Oleh karena itu, manajer Larisso Swalayan Ambulu disarankan untuk menambah motivasi inspiratif dengan cara selalu mendorong karyawannya untuk memiliki inisiatif dalam bekerja agar bekerja tidak terasa jenuh.
Anoraga, P. 2000, Manajemen Bisnis. Cetakan kedua. Jakarta: Rineke Cipta.

Arikunto, S. 2002. Prosedur Penelitian Suatu Pendekatan. Jakarta: Rineke Cipta. 
Dessler. 2002. Management: Concepts and Applications. Hasper Collins Publisher. Inc. NewYork. Terjemahan Ambarruani A.S. Jakarta: Salemba Empat.

Dharma, A. 2001. Manajemen Personalia. Edisi 3. Terjemahan Jakarta: Erlangga.

Ghozali, I. 2001. Aplikasi Analisis Multivatiate dengan Program IBM SPSS 19 (edisi Kelima). Semarang: Universitas Diponegoro.

Gibson. 2006. Organisasi dan Manajemen: Perilaku. Struktur dan Proses. Edisi Keempat. Jakarta: Erlangga.

Gomes, F. Cardoso. 2000. Manajemen Sumber Daya Manusia. Edisi Pertama. Cetakan Pertama. Yogyakarta: Andi Offset.

Gujarati, D. 2003. Basic Econometrics. Fouth Edition. Singapore: McGraw-Hill.

Hasibuan, M. 2001. Organisasi dan Motivasi. Jakarta: Bumi Aksara.

Heidjrachman dan Husna, S. 2002. Manajemen Personalia, Edisi Keempat, Yogyakarta: BMFE.

Hasan, Iqbal. 2008. Analisis Data Penelitian dengan Statistik. Jakarta: Bumi Aksara.

Indrawijaya, AA. I. 2000. Perilaku Organisasi. Cetakan ke-7.
Bandung: Sinar Baru Algesindo.

Manulang, M. 2001. Pengantar Ekonomi Perusahaan. Edisi Revisi. Cetakan Ke Tujuh Belas. Yogyakarta: Liberty.

Mangkunegara, PP. Anwar. 2005. Manajemen Sumber Daya Manusia. Cetakan ke-3. Bandung: Remaja Rosdakarya.

Siagian, SSP. 2001. Teori Motivasi dan Aplikasinya. Jakarta: Rineka Cipta.

Simamora, HH. 2006. Manajemen Sumber Daya Manusia. Edisi Ketiga. Yogyakarta: STIE YKPN.

Sugiyono. 2008. Metode Penelitian Bisnis.Cetakan Keempat. Bandung: Alfabeta. . 2013. Metode Penelitian Kuantitatif, Kualitatif dan $R \& D$. Bandung: Alfabeta.

Sutrisno. E. 2010. Manajemen Sumber Daya Manusia. Edisi Pertama. Cetakan Kedua. Jakarta: Kencana Prenada Group.

Veithzal. R. 2004. Manajemen Sumber Daya Manusia untuk Perusahaan dari Teori ke Praktik. Edisi Pertama. Cetakan Pertama. Jakarta: Raja Grafindo Persada.

Widayat. 2000. Teknik Analisis Regresi dan Korelasi bagi Para Peneliti. Bandung. 